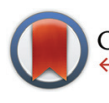

CrossMark $\leftarrow$ click for updates

Cite this: Dalton Trans., 2016, 45 2180

Received 11th August 2015, Accepted 29th October 2015

DOI: $10.1039 / c 5 d t 03107 a$

www.rsc.org/dalton

\section{[3]Ferrocenophanes with the bisphosphanotetryl bridge: inorganic rings on the way to tetrylenes $\uparrow$ t.}

\author{
Denis Kargin, ${ }^{a}$ Zsolt Kelemen, ${ }^{\mathrm{b}}$ Kristijan Krekić, ${ }^{\mathrm{a}}$ Martin Maurer, ${ }^{a}$ Clemens Bruhn, ${ }^{\mathrm{a}}$ \\ László Nyulászi ${ }^{\star b}$ and Rudolf Pietschnig*a
}

\begin{abstract}
A series of [3]ferrocenophanes with functional P-E-P motifs ( $E=$ group 14 fragments) is reported. Out of these, the silicon compounds with the general formula Fe $\left(\mathrm{C}_{5} \mathrm{H}_{4} \mathrm{PtBu}\right)_{2} \mathrm{SiXY}\left(\mathrm{XY}=\mathrm{Cl}_{2}, \mathrm{Br}_{2}, \mathrm{I}_{2}, \mathrm{H}_{2}, \mathrm{HCl}\right)$ have been characterized by spectroscopic means and the bonding situation was analyzed using $\mathrm{X}$-ray crystallography and quantum chemical calculations. Despite the two stereogenic phosphanyl centers, most of the [3]ferrocenophanes have been obtained as single isomers in the course of stereospecific reactions. The corresponding stannylene $\mathrm{Fe}\left(\mathrm{C}_{5} \mathrm{H}_{4} \mathrm{PtBu}\right)_{2} \mathrm{Sn}$ has been obtained in the form of its dimeric adduct.
\end{abstract}

\section{Introduction}

$[n]$ Ferrocenophanes, in which $n$ atoms connect the two cyclopentadienyl rings within a ferrocene molecule, are attractive monomers for the ring opening polymerization (ROP) to ferrocene based polymers. ${ }^{1-4}$ The ring strain present in ferrocenophanes with short bridging units $(n=1)$ leads to structural peculiarities usually described as ring tilt which may involve direct interaction of the iron center with the bridging atom. ${ }^{5,6}$ For bridging units with $n=2,3$ some ring tilts may still be present but the tendency for thermal ROP is significantly reduced. ${ }^{7-9}$ Recently the unique setting in [3]ferrocenophanes has been used to prepare ferrocenylene bridged carbenes where for the corresponding cation direct interactions between iron and the cationic carbon atom have been suggested. ${ }^{10,11}$ Owing to our own interest in the low-coordinate chemistry of group 14 elements we wondered whether it might be feasible to embed heavier tetrylenes into a bridging unit of a [3]ferrocenophane with flanking phosphanyl groups. ${ }^{12-17}$ Few years ago, Power et al. have shown that a low-valent silylene center can be stabilized using two adjacent third row elements. ${ }^{18}$ Therefore, we set out to investigate the possibility to access bisphosphano substituted tetrylenes embedded into a [3]ferrocenophane unit.

\footnotetext{
${ }^{a}$ Universität Kassel, Institut für Chemie und CINSaT, Heinrich-Plett-Straße 40, 34132 Kassel, Germany.E-mail: pietschnig@uni-kassel.de

${ }^{b}$ Budapest University of Technology and Economics, Department of Inorganic and Analytical Chemistry, Szent Gellért tér 4, H-1111 Budapest, Hungary

$\dagger$ Dedicated to the memory of Andreas Kirchmeier.

$\$$ Electronic supplementary information (ESI) available: Details and selected data of quantum chemical calculations. CCDC 1417298-1417301 and 1434408. For ESI and crystallographic data in CIF or other electronic format see DOI: 10.1039/ c5dt03107a
}

\section{Results and discussion}

\section{Synthesis of P-Si-P [3]ferrocenophanes}

A straightforward approach to $\mathrm{P}-\mathrm{Si}-\mathrm{P}$ bridged [3]ferrocenophanes starts from secondary 1,1'-ferrocenylene bisphosphanes in which the bridging unit is closed by attachment of the group 14 elements. We selected bisphosphane 2 as the starting point of this investigation because the $t$-butyl groups should provide some steric protection and furthermore may serve as useful probes in proton NMR spectroscopy. Phosphane 2 is readily prepared with lithium aluminium hydride from the corresponding chlorophosphane $\mathbf{1}$ which has been reported earlier in the literature (Scheme 1). ${ }^{8,19}$

Lithiation with $n$-BuLi affords dilithiophosphanide 3 which was identified by multinuclear NMR spectroscopy. The salient feature of compound 3 is the symmetric bridging of the two lithium atoms between the phosphorus atoms in solution which is evident from the ${ }^{31} \mathrm{P}$ and ${ }^{7} \mathrm{Li}$ NMR spectra showing

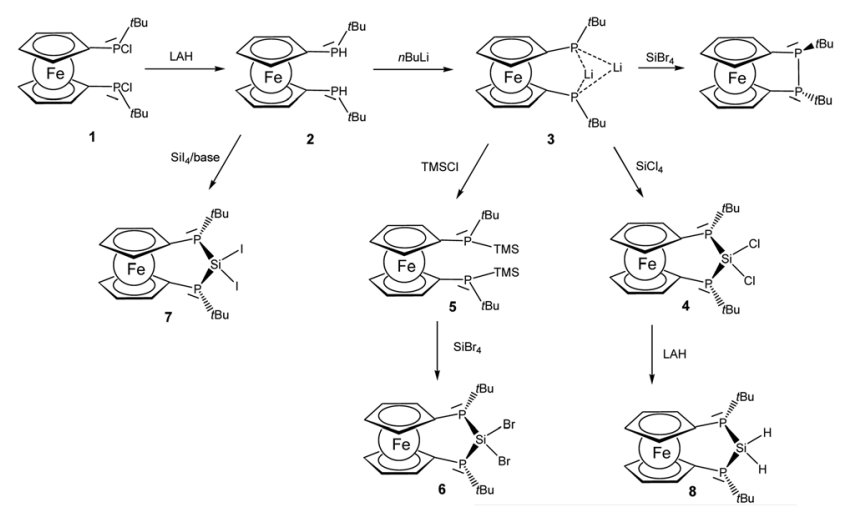

Scheme 1 Formation of [3]ferrocenophanes 4, 6-8 (TMSCl: trimethylsilyl chloride, LAH: lithium aluminium hydride). 


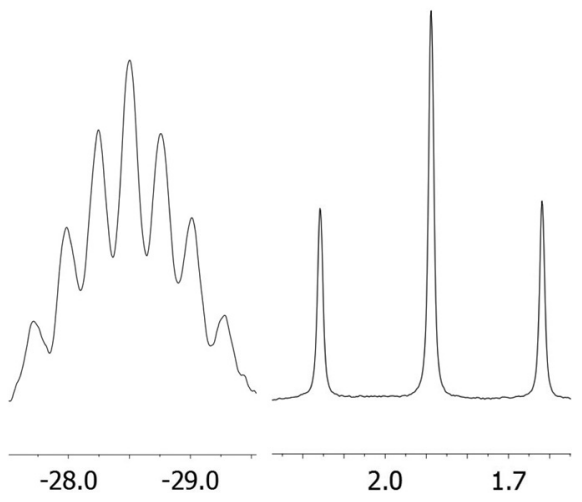

Fig. $1{ }^{31} \mathrm{P}$ (left) and ${ }^{7} \mathrm{Li}$ (right) NMR spectra of 3 in pentane solution.

identical coupling from each lithium to both phosphorus nuclei (Fig. 1) in analogy to related dimeric lithium and alkali phosphanides in the literature. ${ }^{20,21}$ Therefore, the stereochemical situation in 2 consisting of two diastereomers ( $r a c$ and meso) is reset by lithiation which converts the phosphorus atoms to prochiral centers. We have also optimized the possible structures of 3 using B3LYP/6-311+G** DFT calculations, starting from asymmetric structures, with the $t \mathrm{Bu}$ groups either at the same ("cis") or at the opposite side ("trans") of the phosphorus atoms. During the optimization of the "trans" structure the fully symmetrical 3 (Fig. S1 of the ESI obtained, which is in accordance with the NMR data. The "cis" structure $3^{\prime}$ (Fig. S1 of the ESI\$) could also be located, however, it is by $17.2 \mathrm{kcal} \mathrm{mol}^{-1}$ less stable.

The reactivity of dilithiated 3 towards electrophilic silanes reveals a delicate balance between substitution and reduction where the electrophilicity of the silane is crucial. Thus the reaction of 3 with silicon tetrachloride furnishes $\mathrm{P}-\mathrm{Si}-\mathrm{P}$ bridged [3]ferrocenophane 4 .

The ${ }^{29} \mathrm{Si}$ resonance of compound 4 at $21.0 \mathrm{ppm}$ indicates the presence of a dichlorosilane and the ${ }^{1} J_{\mathrm{Sip}}$ coupling pattern shows a triplet with a coupling constant of $88 \mathrm{~Hz}$. Also the ${ }^{31} \mathrm{P}$ NMR data indicate the presence of only one isomer in which the phosphanyl units are chemically and magnetically equivalent $\left(\delta\left({ }^{31} \mathrm{P}\right)=-38.8 \mathrm{ppm}\right)$. By contrast the reaction of 3 with silicon tetrabromide is unselective and indicates predominant oxidation of 3 to the corresponding [2]ferrocenophane $(\mathrm{CpP} t \mathrm{Bu})_{2} \mathrm{Fe}$ which is known from the literature. ${ }^{8}$ The connection of the two phosphanide units in 3 with a dibromosilanyl unit can, however, be accomplished by switching from a LiCl to a silyl halide elimination strategy. For this purpose phosphanide $\mathbf{3}$ is smoothly converted to the corresponding silylphosphane 5. From the multinuclear NMR data of $\mathbf{5}$ it is evident that the prochiral situation in 3 changes to a stereochemically unbiased situation in $\mathbf{5}$ where the ratio of rac and meso diastereomers occurs in a statistical mixture. For the meso form of $\mathbf{5}$ the molecular structure has been determined by Xray diffraction and agrees well with the constitution established by spectroscopic methods (for details see ESI\$). The reaction of silylphosphane 5 with silicon tetrabromide then
Table 1 Survey of heteronuclear NMR data of compounds 4, 6, and 7

\begin{tabular}{lllcc}
\hline $\mathrm{P}-\mathrm{E}-\mathrm{P}$ & & $\delta\left({ }^{31} \mathrm{P}\right)[\mathrm{ppm}]$ & $\delta\left({ }^{29} \mathrm{Si}\right)[\mathrm{ppm}]$ & ${ }^{3} J_{\mathrm{SiP}}[\mathrm{Hz}]$ \\
\hline $\mathrm{SiCl}_{2}$ & $\mathbf{4}$ & -38.8 & +21.0 & 88 \\
$\mathrm{SiBr}_{2}$ & $\mathbf{6}$ & -30.8 & +1.6 & 102 \\
$\mathrm{SiI}_{2}$ & 7 & -18.4 & -63.5 & 112 \\
\hline
\end{tabular}

cleanly affords dibromosilane 6. Multinuclear NMR data of the bulk material show that during the formation of $\mathbf{6}$, just as in the case of $\mathbf{4}$, a stereospecific reaction occurs, in the course of which only a single isomer is formed. Since the reactivity of the silicon halide bond in these ferrocenophanes competes with that of the $\mathrm{P}-\mathrm{Si}$ bonds we considered also the corresponding diiodosilane 7 which can be prepared by reacting 2 with $\mathrm{SiI}_{4}$ in the presence of a base. Again only a single diastereomer can be observed and the ${ }^{29} \mathrm{Si}$ chemical shift at $-63.5 \mathrm{ppm}$ is the most shielded one observed for this series of bisphosphano dihalosilane bridged [3]ferrocenophanes, 4, 6 and 7. Within this series a clear trend can be derived from the heteronuclear NMR data (Table 1). With increasing electronegativity of the halide the silicon nuclei are deshielded, while in turn the corresponding phosphorus resonances appear at higher field. The value of the coupling constant ${ }^{1} J_{\text {Sip }}$ continuously increases on moving from $\mathrm{Cl}$ to $\mathrm{Br}$ and $\mathrm{I}$.

\section{Bonding situation in P-Si-P [3]ferrocenophanes 4, 6 and 7}

For bisphosphanodihalosilyl bridged [3]ferrocenophanes 4 (Fig. 2), 6 (Fig. 3) and 7 (Fig. 4) single crystal structure determinations could be performed. All compounds are isostructural and reveal a stereochemical situation in which both $t$-butyl groups of the phosphanyl units point to the same side of the molecule which is in contrast to cyclic bisphosphano dichlorosilanes from the literature. ${ }^{22}$ Therefore the silyl units are shifted towards the opposite side where the lone pairs of the phosphanyl groups are located.

This stereochemical arrangement of the reaction product is understandable by considering the structure of the reactant 3 , for which no stable "trans"-like arrangement of the $t$ Bu groups could be located. While we did not investigate the mechanism of the reaction in detail here, it is apparent that any incoming silyl-halide reactant will interact at one side of the molecule and accordingly the $t \mathrm{Bu}$ groups should be situated at the other side resulting in the observed stereochemical situation.

All bond lengths and angles for the halogenated compounds are without peculiarities. For each of the compounds the Cp-rings deviate slightly from coplanarity with angles between the normal to the ring plane being $3.52(6)^{\circ}(4)$, $3.10(16)^{\circ}(6)$ and $2.73(8)^{\circ}(7)$ which are equal to the corresponding interplanar angles of the Cp-rings within a molecule. These [3]ferrocenophanes display almost unstrained structures in an eclipsed conformation with the ferrocene backbone opening towards the phosphorus lone pairs of the ansa bridge. The $\mathrm{Fe}$-..Si distance increases, corresponding to the size of the group 17 element (4: 3.7233(6) ̊, 6: 3.7400(11) ^, 7: 3.7624(7) $\AA)$. The halogen atoms $\mathrm{X}$ show two positions, one with an 


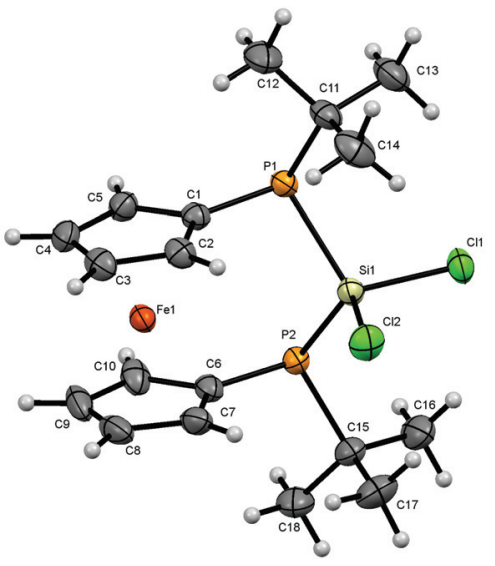

Fig. 2 Molecular structure of 4 . Ellipsoids are drawn at 30\% probability level.

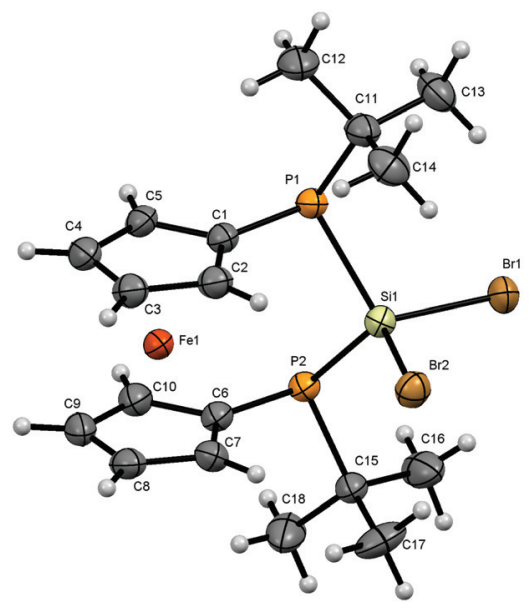

Fig. 3 Molecular structure of 6 . Ellipsoids are drawn at 30\% probability level.

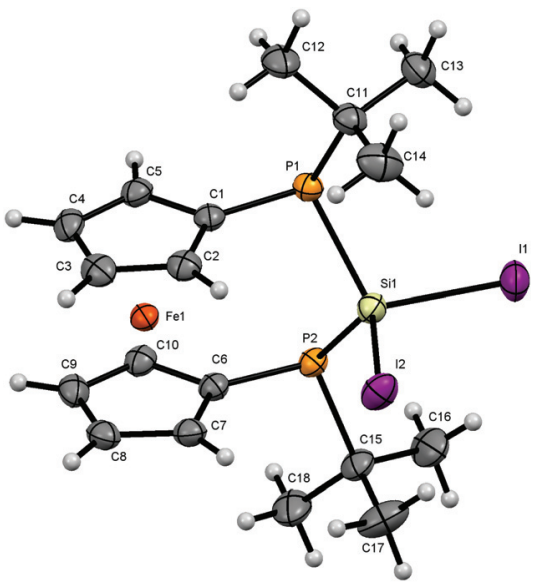

Fig. 4 Molecular structure of 7. Ellipsoids are drawn at 30\% probability level. almost linear $\mathrm{Fe} \cdots \mathrm{Si}-\mathrm{X}$ arrangement $\left(\mathrm{Fe} \cdot \mathrm{Si}-\mathrm{Cl} 1=167.37(2)^{\circ}\right.$, $\left.\mathrm{Fe} \cdots \mathrm{Si}-\mathrm{Br} 1=167.73(4)^{\circ}, \mathrm{Fe} \cdot \mathrm{Si}-\mathrm{I} 1=165.09(2)^{\circ}\right)$ and the other one with an almost perpendicular geometry $(\mathrm{Fe} \cdot \mathrm{Si}-\mathrm{Cl} 2=$ $\left.88.90(2)^{\circ}, \mathrm{Fe} \cdots \mathrm{Si}-\mathrm{Br} 2=89.83(3)^{\circ}, \mathrm{Fe} \cdots \mathrm{Si}-\mathrm{I} 2=90.63(2)^{\circ}\right)$. In the case of substitution with chlorine and bromine, the bond length of the linearly arranged halogen $(\mathrm{Si}-\mathrm{Cl} 1=2.0831(5) \AA$, $\mathrm{Si}-\mathrm{Br} 1=2.2431(10) \AA)$ is slightly longer than the perpendicular one $(\mathrm{Si}-\mathrm{Cl} 2=2.0755(5) \AA, \mathrm{Si}-\mathrm{Br} 2=2.2305(10) \AA)$. In the case of iodine it is vice versa with the perpendicularly arranged halogen being further away (Si-I1 = 2.4736(7) $\AA$, Si-I2 = 2.4835(6) §). It may be anticipated that the difference in bond length could entail a gradual reactivity of the halogen atoms. The dihedral angle at the phosphorus atoms C1P1P2C6 and P1P2Si shows almost identical values for the halogenated compounds (4: $71.85(3)^{\circ}, 6$ : $\left.71.95(7)^{\circ}, 7: 71.12(4)^{\circ}\right)$ but varies in 8. Regarding the sum of the angles at the phosphorus atoms which are in the range between $314^{\circ}$ and $317^{\circ}$ for all compounds a pyramidal structure can be assumed $\left(328^{\circ}\right.$ for tetrahedral conformation, $280^{\circ}$ in $\left.\mathrm{PH}_{3}\right) .^{23}$

The smallest angle is found in between the ipso-CPSi atoms with roughly $100^{\circ}$, indicating a small amount of ring-strain, and the largest angle is between the $t$-butyl groups and the silicon atom amounting to roughly $110^{\circ}$. The angle at the silicon atom between the geminal halogen atoms for the three derivatives 4, 6 and 7 shows values of Cl1SiCl2 $=103.73(2)^{\circ}$, $\operatorname{Br} 1 \mathrm{SiBr} 2=102.42(4)^{\circ}, \mathrm{I} 1 \mathrm{SiI} 2=104.28(2)^{\circ}$.

Our DFT calculations revealed that the other possible stereoisomers of 4, 6 and 7 in which the two $t$-butyl units at the two phosphorus atoms point to different sites of the molecule (Fig. S1 in the ESI + ) exhibit somewhat lower stability (by $3.5 \mathrm{kcal} \mathrm{mol}^{-1}$ for 4 and by $3.7 \mathrm{kcal} \mathrm{mol}^{-1}$ for 6 at the B3LYP/6-311 $+\mathrm{G}^{* *}$ and $3.8 \mathrm{kcal} \mathrm{mol}^{-1}$ for 7 at the B3LYP/Def2TZVP//B3LYP/6-311+G** levels of theory). Since the presence of the other isomer was not observed by NMR spectroscopy even after heating 6 in toluene to $100{ }^{\circ} \mathrm{C}$ for 10 hours, we calculated the barrier between the two isomers, to see whether the isomerisation is kinetically feasible. We could locate a transition state for the interconversion of the two isomers of $\mathbf{4}$ in which one of the phosphorus atoms is planarized (see Fig. S1 in the ESI + . The energy of this transition structure is $19.2 \mathrm{kcal} \mathrm{mol}^{-1}$ at the B3LYP/6-311+G* and $21.6 \mathrm{kcal} \mathrm{mol}^{-1}$ at the M06-2X/ $6-311+\mathrm{G}^{* *}$ levels of theory. Similarly, a $19.1 \mathrm{kcal} \mathrm{mol}^{-1} \mathrm{~B} 3 \mathrm{LYP} /$ $6-311+G^{* *}$ barrier was obtained for 6 . This value is significantly smaller than the usual inversion barrier for phosphorus in phosphanes (for $\mathrm{PH}_{3} 35 \mathrm{kcal} \mathrm{mol}^{-1}$ was reported). ${ }^{24,25}$ However, a similarly low (18 $\mathrm{kcal} \mathrm{mol}^{-1}$ at B3LYP/6-311+G $\left.\mathrm{G}^{* *}\right)^{26}$ barrier was obtained for phosphole, where the reduction of the inversion barrier was attributed to the aromaticity of the planar transition structure. ${ }^{27}$ The lowering of the inversion barrier should at least partly be attributed to the neighbouring silyl group, since the calculated inversion barrier of silyl-phosphane (H3Si-PH2) is $23.8 \mathrm{kcal} \mathrm{mol}^{-1}$ at $\mathrm{B} 3 \mathrm{LYP} / 6-311+\mathrm{G}^{* *}$. Altogether this suggests that the interconversion at higher temperatures might be possible, and very probably the energy difference between the two isomers is large enough to prevent the observation of the isomer shown in Fig. S2 of the ESI.t 
To reveal any suggested direct interaction between the bridging $\mathrm{Si}$ atom and the iron center, the atoms in molecules (AIM) theory was applied but no bond critical point was observed between the Fe and the Si atoms in 4, 6 and 7.

\section{Reactivity of P-Si-P [3]ferrocenophanes}

Dihalosilanes 4, 6 and 7 are promising precursors for the reduction to the corresponding silylene. We tried several reagents to accomplish the dehalogenation including alkali metals, $\mathrm{C}_{8} \mathrm{~K}$, Collman's reagent, Na-naphthalenide and $\left[\left({ }^{\text {Dip }} \mathrm{Nacnac}\right) \mathrm{Mg}\right]_{2} \cdot{ }^{28}$ While we obtained no reaction in the case of Na, K, Collman's and Jones reagents, we observed cleavage of the adjacent $\mathrm{P}-\mathrm{Si}$ bond in the case of sodium-naphthalenide as indicated by the formation of $\mathrm{P}-\mathrm{P}$ coupled products and further unidentified products with no ${ }^{1} J_{\mathrm{PSi}}$-coupling in the ${ }^{29} \mathrm{Si}$ NMR spectra. By contrast, the straightforward reduction of dihalosilane $\mathbf{4}$ to hydrosilane $\mathbf{8}$ is easily achieved by a reaction with lithium aluminium hydride. Again only a single diastereomer is obtained in which the two $\mathrm{Si}-\mathrm{H}$ protons are chemically inequivalent resonating at 4.77 and $4.88 \mathrm{ppm}$. The ${ }^{2} J_{\mathrm{HH}}$ coupling of $9 \mathrm{~Hz}$ is augmented with ${ }^{2} J_{\mathrm{HP}}$ couplings which differ substantially for the two protons. Thus the hydrogen atom resonating at lower field shows a ${ }^{2} J_{\mathrm{HP}}$ coupling constant of $22 \mathrm{~Hz}$ while this coupling is $<1 \mathrm{~Hz}$ for the $\mathrm{Si}-\mathrm{H}$ resonating at higher field. Owing to the predominant s-character of the lone pair at phosphorus it seems plausible to assume that the $\mathrm{Si}-\mathrm{H}$ oriented towards the phosphorus lone-pairs should show a higher $J_{\mathrm{HP}}$ which corresponds to the more deshielded proton.

The pronounced chemical and magnetic inequivalence of the $\mathrm{Si}-\mathrm{H}$ protons indicates a markedly different local molecular environment for both hydrogen atoms as a consequence of the fixed stereo-chemical situation at the phosphorus centers. Although the latter is also the case for halogenated derivatives 4, 6 and 7 based on their crystal structures, in solution it is most easily visible for 8 using NMR spectroscopy. $\mathrm{X}$-ray diffraction on single crystals of $\mathbf{8}$ allowed the determination of the molecular structure of $\mathbf{8}$ in the solid state (Fig. 5).

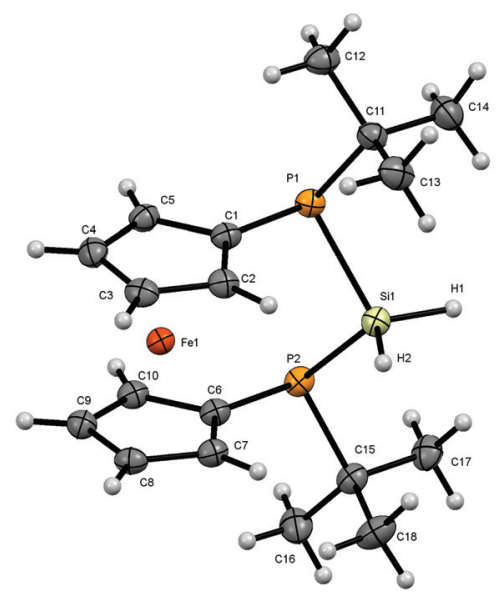

Fig. 5 Molecular structure of $\mathbf{8}$. Ellipsoids are drawn at 30\% probability level. One molecule of solvent (benzene) is omitted for clarity.
Compound $\mathbf{8}$ crystallizes in a triclinic system and together with one molecule of solvent (benzene) (Fig. 5).

The conformation of [3] ferrocenophane $\mathbf{8}$ is very similar to the ones found for halogenated derivatives 4, 6 and 7. Again the Cp-rings in $\mathbf{8}$ deviate slightly from coplanarity with an angle between the normal to the ring plane being $4.44(8)^{\circ}$ which fits into the trend with the halogenated compounds, while the angles at the silicon center vary slightly. Both hydrogen atoms adjacent to the silicon atom have been located and refined. The deviation for an almost linear $\mathrm{Fe} \cdot \mathrm{Si}-\mathrm{H}$ arrangement compared to the halogenated derivatives reaches $4^{\circ}$ towards a higher angle $\left(\mathrm{Fe} \cdot \mathrm{Si}-\mathrm{H} 1=172.34(90)^{\circ}\right)$ and for the corresponding perpendicular geometry $9^{\circ}$ towards a smaller angle $\left(\mathrm{Fe} \cdot \cdot \mathrm{Si}-\mathrm{H} 2=80.17(91)^{\circ}\right)$. The $\mathrm{Si}-\mathrm{H}$ bond lengths show the same behavior as mentioned before with the linear arrangement with respect to the iron center having a slightly longer distance to the silicon atom. Regarding the sum of the angles at the phosphorus atoms, smaller angles in the range between $310^{\circ}$ and $311^{\circ}$, combined with the smaller angle at the silicon atom PSiP $=98.54(3)^{\circ}$ suggest a slightly higher ring strain within the bridge of [3]ferrocenophane 8 compared with the previously discussed compounds in which this angle increases with the electronegativity of the halide (4: P1-Si1-P2 $=102.46(2)^{\circ}, 6:$ P1-Si1-P2 = 100.73(5) $\left.{ }^{\circ}, 7: \mathrm{P} 1-\mathrm{Si} 1-\mathrm{P} 2=100.21(3)^{\circ}\right)$. At the same time the angle at the silicon atom in between the hydrogen atoms is $4^{\circ}$ to $6^{\circ}$ larger than in the halogenated structures $\left(\mathrm{H} 1 \mathrm{SiH} 2=108(1)^{\circ}\right)$. Considering the smaller electronegativity of hydrogen compared to halogens, the increased bond angle is understandable according to the VSEPR theory. ${ }^{29}$ A pyramidal structure at the phosphorus centers can be confirmed as well.

The dihedral angle between the planes C1P1P2C6 and P1P2Si differs by about $4^{\circ}$ to $5^{\circ}$ towards a bigger angle $\left(75.38(4)^{\circ}\right)$ compared with the halogenated derivatives. The distance $\mathrm{Fe}-\mathrm{X}$ for the almost perpendicular geometry is the shortest for the displayed [3]ferrocenophanes $(\mathrm{Fe}-\mathrm{H} 2=3.7305(195) \AA$, $\mathrm{Fe}-\mathrm{Cl} 2=4.2277(6), \mathrm{Fe}-\mathrm{Br} 2=4.3490(7), \mathrm{Fe}-\mathrm{I} 2=4.5319(7) \AA$ ) . Moreover, the Fe...Si distance with 3.7139(7) $\AA$ is also the shortest among the compounds presented here.

Since the $\mathrm{Si}-\mathrm{H}$ protons in $\mathbf{8}$ serve as spectroscopic probes for the difference in the chemical environment of the faces of the ferrocenophane ring, the spectroscopic findings suggest a potentially gradual reactivity for these two hydrogen atoms. This situation is more pronounced for different substituents at silicon for instance in hydrochlorosilane $\mathbf{9}$ which is readily available from silicochloroform and lithiophosphanide $\mathbf{3}$. Owing to the difference in facial orientation above and below the ferrocenophane ring which originates from the orientation of the phosphanyl lone pairs and substituents, two isomers are obtained in the formation of $\mathbf{9}$ (Scheme 2).

The isomers of $\mathbf{9}$ mainly differ in the relative orientation of the substituents at silicon which has substantial impact on the NMR spectroscopic data of the nuclei involved. Again the $\mathrm{Si}-\mathrm{H}$ proton can be used as a spectral probe to assign the resonances to the respective isomers based on the plausible assumption that orientation towards the phosphorus lone- 


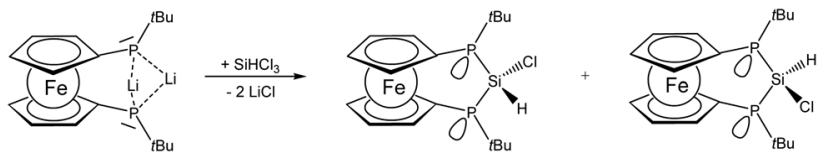

Scheme 2 Formation of [3]ferrocenophane 9 as two diastereomers.

pairs results in an increased $J_{\mathrm{HP}}$. Indeed one isomer of $\mathbf{9}$ shows a markedly higher value for ${ }^{2} J_{\mathrm{HP}}$ of $26 \mathrm{~Hz}$ than the other one $(<1 \mathrm{~Hz})$, which was also in good agreement with our M06-2X/ $6-311+\mathrm{G}^{* * 2} \mathrm{~J}_{\mathrm{HP}}$ values $(1.9$ and $27.1 \mathrm{~Hz}$ for the two isomers, the latter value indeed belonging to hydrogen pointing towards the $\mathrm{P}$ lone pair). The larger ${ }^{2} J_{\mathrm{HP}}$ coupling is accompanied by a deshielded resonance of the corresponding proton at $6.54 \mathrm{ppm}$ while for the isomer with hydrogen pointing away from the phosphorus lone pairs a higher field resonance at $5.91 \mathrm{ppm}$ is observed. Also in the ${ }^{31} \mathrm{P}$ and ${ }^{29} \mathrm{Si}$ NMR spectra shift differences of roughly $20 \mathrm{ppm}$ are found for these two isomers. The isomer with the deshielded $\mathrm{Si}-\mathrm{H}$ proton resonance shows also more deshielded resonances in the ${ }^{31} \mathrm{P}(\delta=$ $-41.7 \mathrm{ppm})$ and ${ }^{29} \mathrm{Si}(\delta=+5.8 \mathrm{ppm})$ NMR spectra compared with the other isomer showing higher field resonances $\left(\delta\left({ }^{31} \mathrm{P}\right)\right.$ $\left.=-62.3 \mathrm{ppm}, \delta\left({ }^{29} \mathrm{Si}\right)=-13.2 \mathrm{ppm}\right)$. For the isomer of 9 with the $\mathrm{Si}-\mathrm{H}$ pointing towards the phosphorus lone-pairs in turn the lone-pairs should adopt an anti periplanar arrangement with respect to chlorine. The interaction of $\sigma^{*}$ states associated with the $\mathrm{Si}-\mathrm{Cl}$ bond may become populated and the corresponding bond order reduced which would explain the general trend of deshielding, as in related cases. ${ }^{15}$ The marked difference in the chemical environment for the two exocyclic substituents at silicon in the two isomers of $\mathbf{9}$ is evident from the spectral data and potentially may be even used to differentiate between the two isomers in terms of reactivity. The ratio of the isomers of 9 slightly varies depending on the reaction conditions employed. At room temperature a ratio of $1.00: 0.75$ is obtained, while at lower temperatures a ratio of $1.00: 0.54$ was observed at $-20{ }^{\circ} \mathrm{C}$ and $-80{ }^{\circ} \mathrm{C}$, respectively. The B3LYP/6$311+\mathrm{G}^{* *}$ and $\mathrm{M} 06-2 \mathrm{X} / 6-311+\mathrm{G}^{* *} / \mathrm{B} 3 \mathrm{LYP} / 6-311+\mathrm{G}^{* *}$ energy difference between the two isomers was only 1.2 and $0.6 \mathrm{kcal}$ $\mathrm{mol}^{-1}$, respectively. This small computed energy difference is in agreement with the observation of both isomers. However, we have not been able to achieve the formation of only one out of the two isomers of $\mathbf{9}$ and also their separation from the mixture remained unsuccessful so far. According to our DFT calculations the interconversion barrier is similar $(21.2 \mathrm{kcal}$ $\mathrm{mol}^{-1}$ at the B3LYP/6-311+G** level of theory) to that of $\mathbf{4}$. Given, however, that in this case the reaction temperature was rather low, it is likely that the two isomers were already formed during the reaction of 3 with $\mathrm{SiHCl}_{3}$.

Formal dehydrohalogenation of $\mathbf{9}$ should lead to the envisaged silylene species, for which higher reactivity compared with N-heterocyclic silylenes can be anticipated owing to the limited $\pi$-donor properties of the phosphanyl unit. However, compound 9 does not react with neutral or anionic nitrogen bases like DBU, DABCO, $\mathrm{NEt}_{3}$ and $\mathrm{LiNTMS}_{2}$ or
$\mathrm{NaNTMS}_{2}$. This is in marked contrast to strained [1]ferrocenophanes with a bridging $>\mathrm{SiHCl}$ unit. ${ }^{30}$ Also N-heterocyclic carbenes (NHCs) induced no reaction of compound $\mathbf{9}$ and did not lead to the envisaged silylene-NHC adducts. ${ }^{31}$

\section{Synthesis of P-E-P [3] ferrocenophanes (E = Sn, Ge)}

Since the generation of a bisphosphano substituted silylene turned out to be difficult, we wondered whether the heavier congeners in group 14 would be more feasible owing to the higher stability of the divalent state for these elements.

The reaction of 3 with $\mathrm{SnCl}_{2}$ furnishes a product where the heteronuclear NMR spectra reveal the formation of the P-Sn-P unit. However, the two phosphorus centers have become inequivalent showing substantially different ${ }^{31} \mathrm{P}$ chemical shift values of $-32.5 \mathrm{ppm}$ and $-94.1 \mathrm{ppm}$ with a much larger coupling of ${ }^{1} J_{\mathrm{SnP}} 1179 \mathrm{~Hz}$ for the phosphorus nucleus resonating at higher field compared with ${ }^{1} J_{\mathrm{SnP}} 702 \mathrm{~Hz}$ for the more deshielded phosphorus nucleus (Fig. 6).

Based on these data and the splitting pattern for the ${ }^{119} \mathrm{Sn}$ resonance at $+418 \mathrm{ppm}$ the formation of stannylene dimers or oligomers seems plausible in which the stannylene units mutually form donor adducts with one of the phosphane units of each other. Owing to its high symmetry the absence of other isomers and the presence of only two resonances for tert-butyl groups in the proton NMR spectra, the dimeric form 10 would be consistent with the observed data (Scheme 3). The instability of the compound precluded further characterization. The bond motif present in $\mathbf{1 0}$ has been first established by $\mathrm{Du}$ Mont et al. for acyclic bisphosphano stannylenes several years ago and the NMR data are in excellent agreement with the reported data. ${ }^{32}$ The reaction of 3 with $\mathrm{GeCl}_{2}$ furnishes a comparable product with ${ }^{31} \mathrm{P}$ chemical shift resonances $-30.8 \mathrm{ppm}$ and $-90.9 \mathrm{ppm}$, however, the product is prone to decompo-

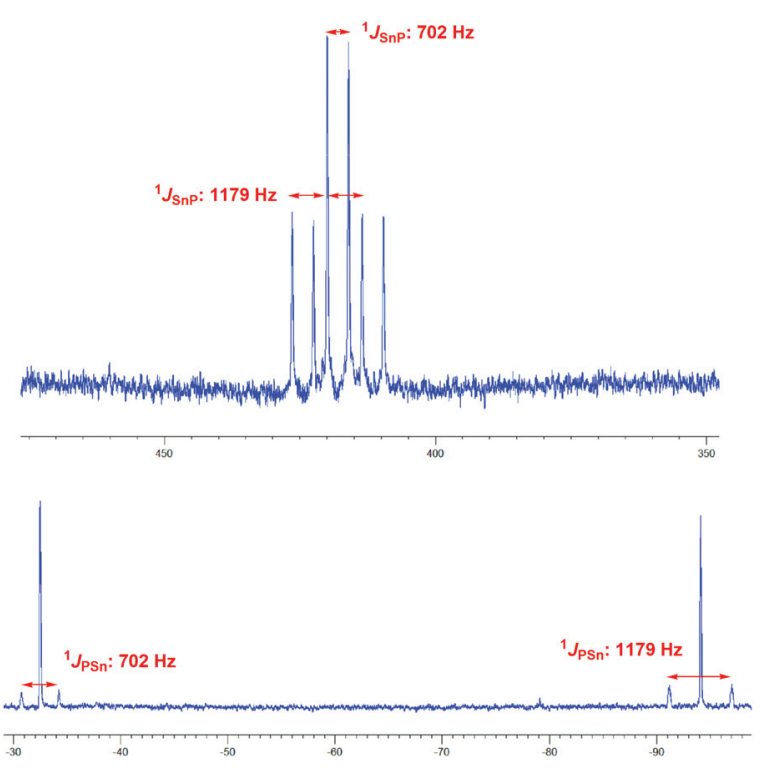

Fig. $6{ }^{119}$ Sn-NMR (top) and ${ }^{31}$ P-NMR (bottom) resonances of 10 in pentane/tetrahydrofuran solution. 

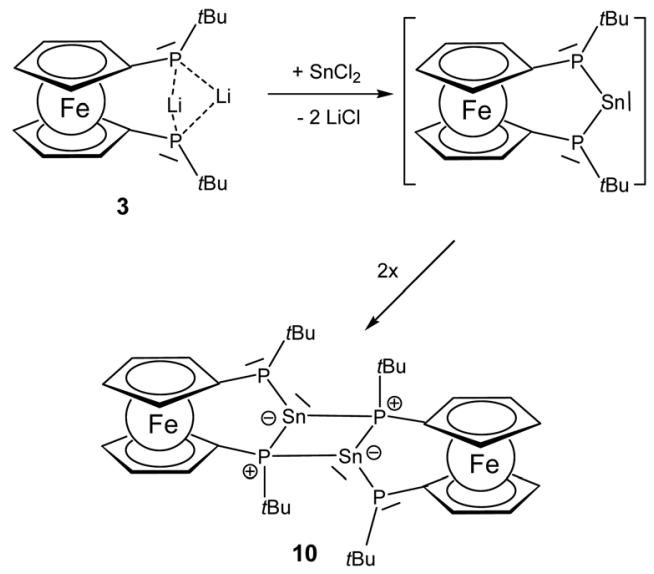

Scheme 3 Illustration of Sn based [3]ferrocenophanes with the tentative formation of dimeric 10 .

sition and could not be isolated. These findings suggest that the $>\mathrm{P}-\mathrm{E}-\mathrm{P}<$ motif ( $\mathrm{E}=$ group 14 elements) can be achieved, however, the steric protection exerted by the $t$-butyl groups at phosphorus is obviously insufficient to prevent dimerization.

Our DFT calculations showed that the dimerization energy to form the four membered ring is $-29.8 \mathrm{kcal} \mathrm{mol}^{-1}$ for the germylene at the M06-2X/cc-pvDZ level of theory, while for the stannylene a slightly smaller value $\left(-28.6 \mathrm{kcal} \mathrm{mol}^{-1}\right)$ was obtained at the M06-2X/cc-pvDZ level of theory (further methods and computational details are given in Table S1 in the ESI + . The isomeric dimeric structure with an $\mathrm{E}=\mathrm{E}$ bond has also been optimized, exhibiting the expected trans-bent structure (Fig. S3 in the ESI + ), which has similar, but somewhat reduced stability both for $\mathrm{E}$ : Ge and $\mathrm{Sn}$ (E: Ge

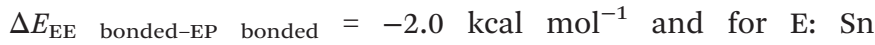

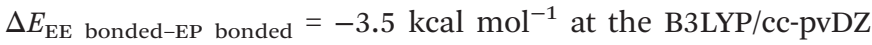
level of theory). Similar relative stability was reported for aminosilylenes. $^{33}$ Since the energy of the dimerization is small, the entropy contribution has a significant effect and the room temperature calculated gas phase Gibbs free energy of the dimerization process is not extremely high $(\Delta G=-12.3$ for E: Ge and $\Delta G=-28.6$ for E: Sn). Thus, we predict that with bigger substituents at the phosphorus atoms this dimerization process can be blocked, or alternatively, an equilibrium between the monomeric and dimeric structures might be feasible for both compounds.

\section{Conclusions}

In summary, we have prepared a series of [3]ferrocenophanes with functional $\mathrm{P}-\mathrm{E}-\mathrm{P}$ motifs ( $\mathrm{E}=$ group 14 fragments). Although these compounds are promising precursors for the generation of the corresponding tetrylenes, only in the case of tin a stannylene has been obtained in the form of a dimeric mutual donor acceptor adduct. With respect to the stereogenic phosphanyl centers, compounds 4, 6-8 are formed in a sur- prisingly stereospecific reaction from prochiral 3 as well as from rac-meso mixed 2 and 5. The molecular structures based on X-ray diffraction indicate no relevant ring strain in these [3]ferrocenophanes which suggests a low propensity to undergo thermal ROP. Future work will focus on increasing the steric congestion at the flanking phosphanyl units to prevent dimerization and to tame the reactivity of the related tetrylenes.

\section{Experimental}

All manipulations were carried out under strict exclusion of moisture and air under an inert argon atmosphere. All used solvents were dried over sodium potassium alloy or $\mathrm{CaH}_{2}$ and distilled prior to use. Starting materials $(\mathrm{CpP}(\mathrm{Cl}) t \mathrm{Bu})_{2} \mathrm{Fe}, \mathrm{SiBr}_{4}$ and DipNHC were synthesized according to the literature procedures. ${ }^{8,34,35}{ }^{1} \mathrm{H},{ }^{13} \mathrm{C},{ }^{31} \mathrm{P},{ }^{29} \mathrm{Si}$ and ${ }^{119} \mathrm{Sn}$-NMR spectra were recorded on a Varian VNMRS-500 $\mathrm{MHz}$ or MR-400 MHzspectrometer at room temperature using TMS as the external reference for ${ }^{1} \mathrm{H},{ }^{13} \mathrm{C}$ and ${ }^{29} \mathrm{Si}$. ESI-MS spectra have been recorded on a microTOF (Bruker Daltonics). LIFDI-MS spectra have been recorded on an AccuTOF GCv (Jeol).

\section{X-ray diffraction measurements}

X-ray diffraction measurements were performed on a Stoe 4CD or a Bruker-AXS SMART APEX 2 CCD diffractometer using graphite-monochromated Mo K $\alpha$ radiation or a Stoe StadiVari with a Dectris Pilatus $200 \mathrm{~K}$ detector using monochromated $\mathrm{Cu} \mathrm{K}_{\alpha}$ radiation (Table 2). The structures were solved using direct methods and refined by full-matrix least-squares techniques against $F^{2}$ (SHELXL-2014/6). ${ }^{36}$ Details of the structure determinations and refinement for 4, 5, 6, 7 and 8 are summarized in Table 2. Further programs used for analysis and visualisation of structural information include WinGX, Parst and Mercury. ${ }^{37-39}$ Supplementary crystallographic data for this paper can be obtained by quoting CCDC 1417298-1417301 and 1434408.

\section{Quantum chemical calculations}

Quantum chemical calculations were performed using the Gaussian 09 suite of programs..$^{40}$ Geometry optimizations were carried out using the M06-2X or B3LYP functional with the $6-31 G^{*}, 6-31+G^{*}$, and $6-311+G^{* *}$ cc-pVDZ basis sets. For the Sn and I containing systems Def2-TZVP basis was used for the Sn and I atoms. For the energy difference between the isomeric/ dimeric structures, further single point energy calculations were carried out at the B3LYP/Def2-TZVP level. The nature of the stationary point obtained by geometry optimization has been verified by a subsequent analysis of the second derivatives, which have been found all positive in the case of minima, and exhibited a single negative value in the case of transition states. The structures were visualized by the MOLDEN package. ${ }^{41}$ The topological analysis of the electron density was carried out by the AIMAll package. ${ }^{42}$ 
Table 2 Summary of structure determinations and refinement for 4, 6, 7 and 8 (for details of the structure determination of 5 see ESI)

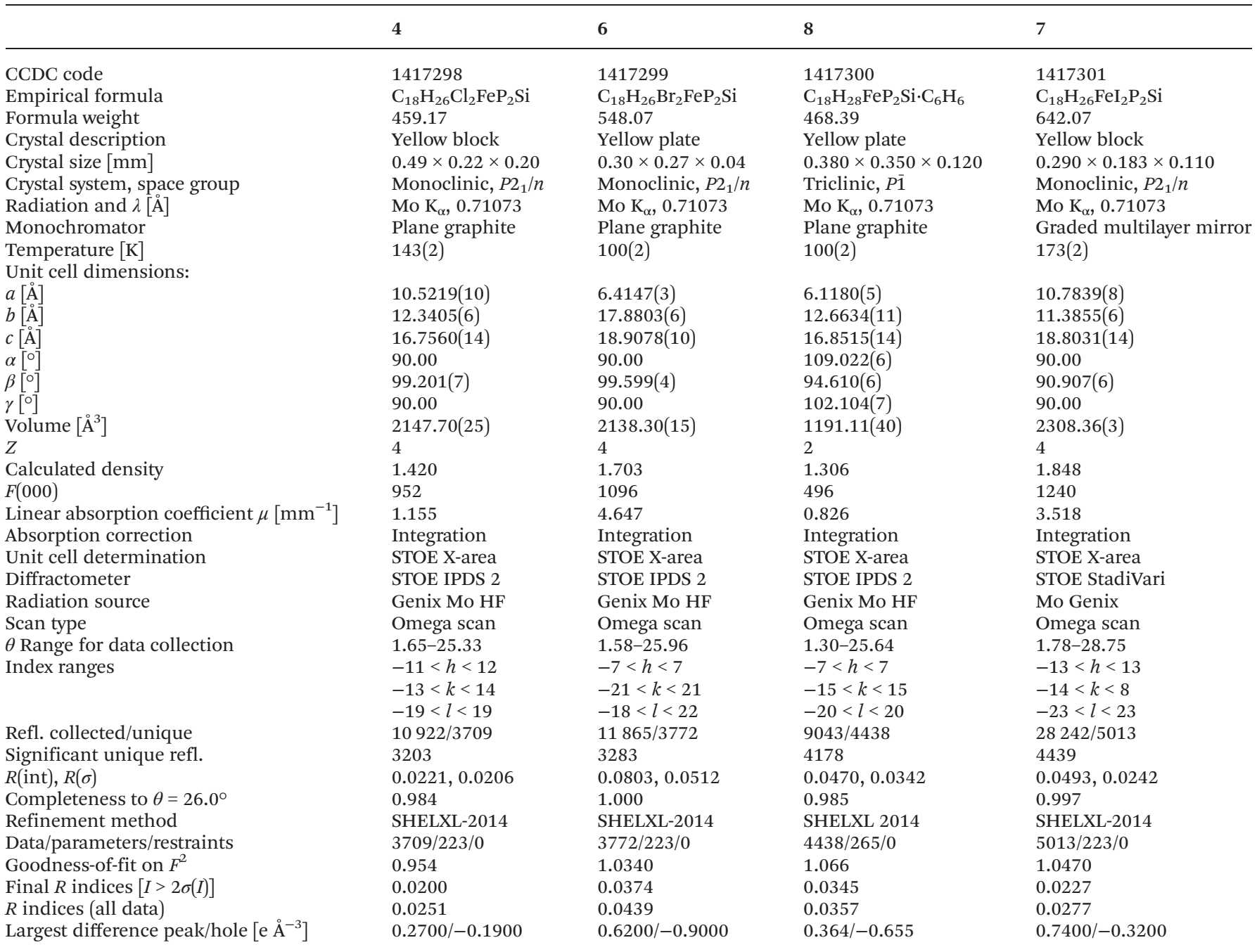

\section{Synthesis of 2}

To a suspension of $\mathrm{LiAlH}_{4}(637 \mathrm{mg}, 16.8 \mathrm{mmol})$ in $20 \mathrm{~mL}$ of $\mathrm{Et}_{2} \mathrm{O}$, a solution of $1(7.26 \mathrm{~g}, 16.8 \mathrm{mmol})$ in $100 \mathrm{~mL} \mathrm{Et}_{2} \mathrm{O}$ was added. The reaction mixture was stirred for 15 minutes and degassed water was added until the evolution of gas stopped. The residue was extracted with $\mathrm{Et}_{2} \mathrm{O}$ and the organic layer was washed with water and brine. The organic layer was dried with $\mathrm{MgSO}_{4}$ and the solvent was removed in vacuo. Recrystallization from pentane yielded $85 \%$ product $(5.15 \mathrm{~g}, 14.2 \mathrm{mmol})$ as orange crystals.

${ }^{31} \mathrm{P}$ NMR $\left(202 \mathrm{MHz}, \mathrm{C}_{6} \mathrm{D}_{6}\right) \delta:-26.9\left(\mathrm{~d},{ }^{1} J_{\mathrm{PH}}=206 \mathrm{~Hz}\right),-27.4$ $\left(\mathrm{d},{ }^{1} J_{\mathrm{PH}}=208 \mathrm{~Hz}\right) \mathrm{ppm} ;{ }^{1} \mathrm{H}$ NMR $\left(400 \mathrm{MHz}, \mathrm{C}_{6} \mathrm{D}_{6}\right) \delta: 4.32-4.26$ (pseudo d, $J=6.1 \mathrm{~Hz}, 2 \mathrm{H} \mathrm{Cp}$ ), 4.20-4.14 (pseudo d, $J=7.7 \mathrm{~Hz}$, $4 \mathrm{H} \mathrm{Cp}$ ), 4.10-4.04 (pseudo d, $J=10.4 \mathrm{~Hz}, 2 \mathrm{H} \mathrm{Cp}$ ), 3.95 (d, ${ }^{1} J_{\mathrm{PH}}$ $=207.6 \mathrm{~Hz}, 1 \mathrm{H} \mathrm{PH}), 3.93\left(\mathrm{~d},{ }^{1} J_{\mathrm{PH}}=204.3 \mathrm{~Hz}, 1 \mathrm{H} \mathrm{PH}\right), 1.09-1.02$ (pseudo d, $\left.{ }^{3} J_{\mathrm{PH}}=12.0 \mathrm{~Hz}, 18 \mathrm{H} \mathrm{CH}_{3}\right) \mathrm{ppm} ;{ }^{13} \mathrm{C}$ NMR $(101 \mathrm{MHz}$, $\mathrm{C}_{6} \mathrm{D}_{6}$ ) $\delta:$ 78.0-77.0 (m Cp), 76.8-76.3 (m Cp), 72.7-72.4 (m Cp), 71.8-71.5 (m Cp ipso C), 30.1-29.6 (m ${ }^{t} \mathrm{Bu} \mathrm{CH}_{3}$ ), 29.0-28.8 ( ${ }^{t} \mathrm{Bu} \mathrm{C}$ q) ppm. Elemental analysis calculated: C: 59.69,
H: 7.79, found: C: 59.97, H: 8.02. MS (ESI-HR) $m / z 831.110591$ $\left([2 \mathrm{M}+\mathrm{Ag}]^{+} 100 \%\right)$ calculated: 831.108243 .

\section{Synthesis of 3}

To a solution of 2 (362 mg, $1 \mathrm{mmol})$, a solution of $n$-BuLi in hexane $(0.88 \mathrm{~mL}, 2 \mathrm{mmol}, 2.5 \mathrm{M})$ and TMEDA $(0.33 \mathrm{~mL}$, $2 \mathrm{mmol}$ ) were added at room temperature. This mixture was stirred for $12 \mathrm{~h}$ forming a yellow solid within a red solution. This slurry was used in situ for further reactions.

${ }^{31} \mathrm{P}$ NMR (202 MHz, $\left.\mathrm{C}_{6} \mathrm{D}_{6}\right) \delta:-28.5$ (sept) ppm; ${ }^{7} \mathrm{Li}$ NMR $\left(194 \mathrm{MHz}, \mathrm{C}_{6} \mathrm{D}_{6}\right) \delta: 1.89\left(\mathrm{t},{ }^{1} J_{\mathrm{PLi}}=52.4 \mathrm{~Hz}\right) \mathrm{ppm}$.

\section{Synthesis of 4}

$\mathrm{SiCl}_{4}(0.88 \mathrm{ml}, 2 \mathrm{mmol})$ was added to the stirred slurry of 3 at room temperature and stirring was continued for 10 minutes. All volatile components were removed in vacuo, the residue was extracted with $30 \mathrm{~mL}$ of pentane and the solid was removed and discarded. The pentane extract was evaporated to dryness 
yielding the raw product. Recrystallization from pentane afforded $91 \%$ yield ( $417 \mathrm{mg}, 0.91 \mathrm{mmol}$ ) as orange crystals.

${ }^{31} \mathrm{P}$ NMR $\left(202 \mathrm{MHz}, \mathrm{C}_{6} \mathrm{D}_{6}\right) \delta:-38.8\left({ }^{1} J_{\mathrm{Psi}}=88 \mathrm{~Hz}\right) \mathrm{ppm}$; ${ }^{29} \mathrm{Si}$ NMR (99 MHz, $\left.\mathrm{C}_{6} \mathrm{D}_{6}\right) \delta: 21.0\left(\mathrm{t},{ }^{1} J_{\mathrm{Psi}}=88 \mathrm{~Hz}\right) \mathrm{ppm}$; ${ }^{1} \mathrm{H}$ NMR (500 MHz, $\mathrm{C}_{6} \mathrm{D}_{6}$ ) $\delta: 4.64-4.61$ (m, 2H Cp), 4.13-4.10 (m, 2H Cp), 4.07-4.04 (m, 2H Cp), 4.01-3.98 (m, 2H Cp), 1.34-1.29 (m, 18H CH 3 ) ppm; ${ }^{13} \mathrm{C}$ NMR (126 MHz, $\left.\mathrm{C}_{6} \mathrm{D}_{6}\right)$ $\delta: 79.6$ (pseudo t, $J_{\mathrm{PC}}=22.2 \mathrm{~Hz}, \mathrm{Cp}$ ), 76.2 (pseudo t, $J_{\mathrm{PC}}=3.8 \mathrm{~Hz}$, Cp), 73.2 (m Cp), 72.2 (pseudo t, $J_{\mathrm{PC}}=5.4 \mathrm{~Hz}, \mathrm{Cp}$ ), 66.0 (pseudo t, $J_{\mathrm{PC}}=10.0 \mathrm{~Hz}$, Cp ipso C), 34.0-33.8 (m ${ }^{t} \mathrm{Bu} \mathrm{C} \mathrm{q)}, 31.2$ (pseudo t, $6.9 \mathrm{~Hz},{ }^{t} \mathrm{Bu} \mathrm{CH}_{3}$ ) ppm. Elemental analysis (\%) for $\mathrm{C}_{18} \mathrm{H}_{26} \mathrm{Cl}_{2} \mathrm{FeP}_{2} \mathrm{Si} \cdot 0.15 \mathrm{C}_{18} \mathrm{H}_{28} \mathrm{FeP}_{2}$ calculated: C: 48.624, $\mathrm{H}:$ 5.961, found: $\mathrm{C}:$ 48.778, $\mathrm{H}:$ 5.820. MS (LIFDI-HR): $m / z 362.10107\left(\left[\mathrm{M}-\mathrm{SiCl}_{2}+2 \mathrm{H}\right]^{+} 100 \%\right), 396.06346([\mathrm{M}-\mathrm{SiCl}$ $+\mathrm{H}]^{+}$3\%) calculated: 396.06259 .

\section{Synthesis of 5}

TMSCl $(0.25 \mathrm{ml}, 2 \mathrm{mmol})$ was added to the stirred slurry of 3 at room temperature and stirring was continued for 10 minutes. All volatile components were removed in vacuo, the residue was extracted with $30 \mathrm{~mL}$ of pentane and the solid was removed and discarded. The pentane extract was evaporated to dryness yielding the raw product. Recrystallization from pentane afforded an orange-brown powder in $80 \%$ yield (407 mg, $0.8 \mathrm{mmol}$ ).

${ }^{31} \mathrm{P}$ NMR $\left(202 \mathrm{MHz}, \mathrm{C}_{6} \mathrm{D}_{6}\right) \delta:-48.4\left({ }^{1} J_{\mathrm{Psi}}=32 \mathrm{~Hz}\right),-48.6$ $\left({ }^{1} J_{\mathrm{Psi}}=32 \mathrm{~Hz}\right) \mathrm{ppm} ;{ }^{29} \mathrm{Si} \mathrm{NMR}\left(99 \mathrm{MHz}, \mathrm{C}_{6} \mathrm{D}_{6}\right) \delta:-1.5\left(\mathrm{t},{ }^{1} J_{\mathrm{Psi}}=\right.$ $32 \mathrm{~Hz}) ;-1.4\left(\mathrm{t},{ }^{1} J_{\mathrm{Psi}}=32 \mathrm{~Hz}\right) \mathrm{ppm} ;{ }^{1} \mathrm{H} \mathrm{NMR}\left(400 \mathrm{MHz}, \mathrm{C}_{6} \mathrm{D}_{6}\right)$ $\delta: 4.34-4.30$ (m, 2H Cp), 4.30-4.27 (m, 2H Cp), 4.27-4.22 (m,

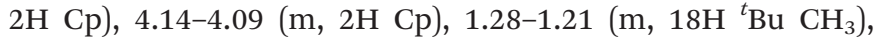
0.35-0.26 (m, 18H TMS CH ${ }_{3}$ ppm; ${ }^{13} \mathrm{C} \mathrm{NMR} \mathrm{(101} \mathrm{MHz,} \mathrm{C}_{6} \mathrm{D}_{6}$ ) 8: 77.2-76.7 (m ipso C Cp), 74.6-74.2 (m Cp), 73.9-73.5 (m Cp), 72.6-72.3 (m Cp), 72.3-71.9 (m Cp), 32.1-31.8 (m ${ }^{t} \mathrm{Bu}^{\mathrm{CH}_{3}}$ ), 31.5-31.3 (m $\left.{ }^{t} \mathrm{Bu} \mathrm{C} \mathrm{q}\right), 2.1-1.8$ (m TMS CH${ }_{3}$ ) ppm.

\section{Synthesis of 6}

To a solution of $5(2.02 \mathrm{~g}, 4 \mathrm{mmol})$ in $15 \mathrm{~mL}$ toluene, $\mathrm{SiBr}_{4}$ $(0.56 \mathrm{~mL}, 4.5 \mathrm{mmol})$ was added at room temperature and the reaction mixture was heated to $100{ }^{\circ} \mathrm{C}$ for 4 hours. All volatile components were removed in vacuo, the residue was extracted with $40 \mathrm{~mL}$ of pentane and the solid was removed and discarded. The pentane extract was evaporated to dryness yielding the raw product. Recrystallization from pentane afforded 6 in $63 \%$ yield ( $1.37 \mathrm{~g}, 2.5 \mathrm{mmol})$ as orange crystals.

${ }^{31} \mathrm{P}$ NMR (202 MHz, $\left.\mathrm{C}_{6} \mathrm{D}_{6}\right) \delta:-30.8\left({ }^{1} J_{\mathrm{PSi}}=102 \mathrm{~Hz}\right) \mathrm{ppm}$; ${ }^{29} \mathrm{Si} \mathrm{NMR}\left(99 \mathrm{MHz}, \mathrm{C}_{6} \mathrm{D}_{6}\right) \delta: 1.6\left(\mathrm{t},{ }^{1} J_{\mathrm{SiP}}=102 \mathrm{~Hz}\right) \mathrm{ppm} ;{ }^{1} \mathrm{H}$ NMR (500 MHz, $\mathrm{C}_{6} \mathrm{D}_{6}$ ) $\delta: 4.81-4.71$ (m, 2H Cp), 4.13-4.08 (m, 2H Cp), 4.08-4.03 (m, 2H Cp), 4.01-3.93 (m, 2H Cp), 1.50-1.18 $\left(\mathrm{m}, 18 \mathrm{H}{ }^{t} \mathrm{Bu} \mathrm{CH}_{3}\right) \mathrm{ppm} ;{ }^{13} \mathrm{C} \mathrm{NMR}\left(101 \mathrm{MHz}, \mathrm{C}_{6} \mathrm{D}_{6}\right) \delta: 79.68$ (pseudo t, $J_{\mathrm{PC}}=22.1 \mathrm{~Hz}, \mathrm{Cp}$ ), 75.69 (pseudo t, $J_{\mathrm{PC}}=3.7 \mathrm{~Hz}$, Cp), 73.17 (m Cp), 72.05 (pseudo t, $J_{\mathrm{PC}}=5.4 \mathrm{~Hz}, \mathrm{Cp}$ ), 67.48 (pseudo t, $J_{\mathrm{PC}}=10.5 \mathrm{~Hz}, \mathrm{Cp}$ ipso C), 34.63 (pseudo $\mathrm{t}, J_{\mathrm{PC}}=$ $5.7 \mathrm{~Hz},{ }^{t} \mathrm{Bu} \mathrm{C} \mathrm{q}$ ), 31.27 (pseudo t, $J_{\mathrm{PC}}=6.8 \mathrm{~Hz},{ }^{t} \mathrm{Bu} \mathrm{CH}_{3}$ ) ppm. Elemental analysis (\%) $\mathrm{C}_{18} \mathrm{H}_{26} \mathrm{Br}_{2} \mathrm{FeP}_{2} \mathrm{Si}$ calculated: C: 39.446, $\mathrm{H}:$ 4.781, found: $\mathrm{C}: 39.211, \mathrm{H}:$ 4.648. MS (LIFDI-HR): $\mathrm{m} / \mathrm{z}$
$362.10292\left(\left[\mathrm{M}-\mathrm{SiBr}_{2}+2 \mathrm{H}\right]^{+} 100 \%\right), 519.92085\left(\mathrm{M}^{+} 1 \%\right)$ calculated: 519.92054 .

\section{Synthesis of 7}

To a suspension of $\mathrm{SiI}_{4}(550 \mathrm{mg}, 1.02 \mathrm{mmol})$ in $10 \mathrm{~mL}$ of pentane, a solution of $2(363 \mathrm{mg}, 1 \mathrm{mmol})$ in $10 \mathrm{~mL}$ of pentane was added at room temperature. To the reaction mixture $\mathrm{NEt}_{3}(0.29 \mathrm{~mL}, 2.1 \mathrm{mmol})$ was added and stirred for 48 hours and sonicated with ultrasound few times. All volatile components were removed in vacuo, the residue was extracted with $40 \mathrm{~mL}$ of pentane and the solid was removed and discarded. The pentane extract was evaporated to dryness yielding the raw product. Recrystallization from pentane afforded 7 in $45 \%$ yield (290 mg, $0.45 \mathrm{mmol}$ ) as yellow crystals.

${ }^{31} \mathrm{P}$ NMR (202 MHz, $\left.\mathrm{C}_{6} \mathrm{D}_{6}\right) \delta:-18.4(\mathrm{~s}) \mathrm{ppm} .{ }^{29} \mathrm{Si} \mathrm{NMR}$ (99 $\left.\mathrm{MHz}, \mathrm{C}_{6} \mathrm{D}_{6}\right) \delta:-63.5\left(\mathrm{t},{ }^{1} J_{\mathrm{SiP}} 113 \mathrm{~Hz}\right)$ ppm; ${ }^{1} \mathrm{H}$ NMR (500 MHz, $\left.\mathrm{C}_{6} \mathrm{D}_{6}\right) \delta: 4.98-4.93(\mathrm{~m}, 2 \mathrm{H} \mathrm{Cp}), 4.11-4.08(\mathrm{~m}, 2 \mathrm{H}$ Cp), 4.08-4.05 (m, 2H Cp), 3.94-3.91 (m, 2H Cp), 1.42-1.34 (m, $18 \mathrm{H} \mathrm{CH}_{3}$ ) ppm; ${ }^{13} \mathrm{C} \mathrm{NMR}\left(126 \mathrm{MHz}, \mathrm{C}_{6} \mathrm{D}_{6}\right.$ ) $\delta: 79.79$ (pseudo $\mathrm{t}$, $J_{\mathrm{PC}}=21.8 \mathrm{~Hz}, \mathrm{Cp}$ ), 74.12 (pseudo t, $J_{\mathrm{PC}}=3.4 \mathrm{~Hz}, \mathrm{Cp}$ ), 72.96 (m Cp), 71.72 (pseudo t, $J_{\mathrm{PC}}=5.2 \mathrm{~Hz}, \mathrm{Cp}$ ), 70.56 (pseudo t, $J_{\mathrm{PC}}=$ $11.6 \mathrm{~Hz}, \mathrm{Cp}$ ipso C), 35.34 (pseudo $\mathrm{t}, J_{\mathrm{PC}}=6.3 \mathrm{~Hz},{ }^{t} \mathrm{Bu} \mathrm{C} \mathrm{q}$ ), 31.47 (pseudo t, $J_{\mathrm{PC}}=6.7 \mathrm{~Hz},{ }^{t} \mathrm{Bu} \mathrm{CH}_{3}$ ) ppm. Elemental analysis (\%) $\mathrm{C}_{18} \mathrm{H}_{26} \mathrm{I}_{2} \mathrm{FeP}_{2} \mathrm{Si}$ calculated: C: $33.671, \mathrm{H}$ : 4.082 , found: C: 33.852, H: 3.848. MS (LIFDI-HR): $m / z 641.86511\left(\mathrm{M}^{+} 70 \%\right)$ calculated: 641.87178 .

\section{Synthesis of 8}

A solution of 4 (487 mg, $1 \mathrm{mmol}$ ) in $20 \mathrm{~mL}$ pentane was added to a suspension of $\mathrm{LiAlH}_{4}(52 \mathrm{mg}, 1.37 \mathrm{mmol})$ in $15 \mathrm{~mL} \mathrm{Et}{ }_{2} \mathrm{O}$ at $0{ }^{\circ} \mathrm{C}$. The reaction mixture was stirred for 2 hours, and all volatile components were removed in vacuo. The residue was extracted with $30 \mathrm{~mL}$ of pentane and the solid was removed and discarded. The pentane extract was evaporated to dryness yielding the raw product. Recrystallization from benzene afforded the crystalline product.

${ }^{31} \mathrm{P}$ NMR (202 MHz, $\left.\mathrm{C}_{6} \mathrm{D}_{6}\right) \quad \delta:-62.2 \mathrm{ppm} .{ }^{29} \mathrm{Si} \mathrm{NMR}$ $\left(99 \mathrm{MHz}, \mathrm{C}_{6} \mathrm{D}_{6}\right) \delta:-51.6\left(\mathrm{ddt},{ }^{1} J_{\mathrm{SiH}}=196 \mathrm{~Hz}, 187 \mathrm{~Hz},{ }^{1} J_{\mathrm{SiP}}=\right.$ $40 \mathrm{~Hz})$ ppm. ${ }^{1} \mathrm{H}$ NMR $\left(500 \mathrm{MHz}, \mathrm{C}_{6} \mathrm{D}_{6}\right) \delta: 4.88\left(\mathrm{td},{ }^{2} J_{\mathrm{PH}}=\right.$ $\left.21.8 \mathrm{~Hz},{ }^{2} \mathrm{~J}_{\mathrm{HH}}=9.2 \mathrm{~Hz}, 1 \mathrm{H}\right), 4.77\left(\mathrm{~d},{ }^{2} \mathrm{~J}_{\mathrm{HH}}=9.2 \mathrm{~Hz}\right), 4.38-3.92$ (m, 8H Cp), 1.26-1.16 (m, 18H CH $\mathrm{CH}_{3}$ ppm. MS (LIFDI-HR): $\mathrm{m} / \mathrm{z}$ $362.10156\left([\mathrm{M}-\mathrm{Si}]^{+} 100 \%\right), 390.07870\left(\mathrm{M}^{+} 20 \%\right)$ calculated: 390.07849 .

\section{Synthesis of 9}

$\mathrm{SiHCl}_{3}(0.21 \mathrm{~mL}, 2.1 \mathrm{mmol})$ was added to the reaction mixture of 3 and stirred for 10 minutes. All volatile components were removed in vacuo, and the residue was extracted with $30 \mathrm{~mL}$ of pentane. After removal of the solid 9 was obtained as a mixture of two stereo isomers (major/minor, ratio $1.00: 0.75$ ).

9 major: ${ }^{31} \mathrm{P}$ NMR $\left(202 \mathrm{MHz}, \mathrm{C}_{6} \mathrm{D}_{6}\right) \delta:-41.7\left({ }^{1} J_{\mathrm{PSi}}=67 \mathrm{~Hz}\right)$ ppm; $\left.{ }^{29} \mathrm{Si} \mathrm{NMR} \mathrm{(99} \mathrm{MHz,} \mathrm{C}_{6} \mathrm{D}_{6}\right) \delta: 5.8\left(\mathrm{dt},{ }^{1} J_{\mathrm{SiH}}=220 \mathrm{~Hz}, J_{\mathrm{SiP}}=\right.$ $67 \mathrm{~Hz}) \mathrm{ppm} ;{ }^{1} \mathrm{H}$ NMR $\left(500 \mathrm{MHz}, \mathrm{C}_{6} \mathrm{D}_{6}\right) \delta: 6.54\left(\mathrm{t},{ }^{2} J_{\mathrm{HP}}=26.3 \mathrm{~Hz}\right.$, $\left.{ }^{1} J_{\mathrm{HSi}}=219.6 \mathrm{~Hz}, 1 \mathrm{H} \mathrm{SiH}\right), 4.80-3.94$ (m, 8H Cp), $1.33-1.22$ $\left(\mathrm{m}, 18 \mathrm{H}{ }^{t} \mathrm{Bu} \mathrm{CH}_{3}\right) \mathrm{ppm} ;{ }^{13} \mathrm{C} \mathrm{NMR}\left(126 \mathrm{MHz}, \mathrm{C}_{6} \mathrm{D}_{6}\right) \delta: 80.2$ (pseudo t, $J_{\mathrm{PC}}=21.8 \mathrm{~Hz}, \mathrm{Cp}$ ), 77.1 (pseudo t, $J_{\mathrm{PC}}=3.9 \mathrm{~Hz}, \mathrm{Cp}$ ), 
72.6 (m, Cp), 70.9 (pseudo t, $J_{\mathrm{PC}}=10.5 \mathrm{~Hz}$, Cp ipso C), 70.8 (pseudo t, $J_{\mathrm{PC}}=5.4 \mathrm{~Hz}, \mathrm{Cp}$ ), 32.2 (pseudo $\mathrm{t}, J_{\mathrm{PC}}=2.6 \mathrm{~Hz}$, ${ }^{t} \mathrm{Bu} \mathrm{C}$ q), 31.3 (pseudo t, $J_{\mathrm{PC}}=7.0 \mathrm{~Hz},{ }^{t} \mathrm{Bu} \mathrm{CH}_{3}$ ) ppm.

9 minor: ${ }^{31} \mathrm{P}$ NMR $\left(202 \mathrm{MHz}, \mathrm{C}_{6} \mathrm{D}_{6}\right) \delta:-62.3\left({ }^{1} J_{\mathrm{PSi}}=55 \mathrm{~Hz}\right)$ ppm; ${ }^{29} \mathrm{Si}$ NMR $\left(99 \mathrm{MHz}, \mathrm{C}_{6} \mathrm{D}_{6}\right) \delta:-13.2\left(\mathrm{dt}, J_{\mathrm{SiH}}=223 \mathrm{~Hz}, J_{\mathrm{SiP}}\right.$ $=55 \mathrm{~Hz}) \mathrm{ppm} ;{ }^{1} \mathrm{H}$ NMR $\left(500 \mathrm{MHz}, \mathrm{C}_{6} \mathrm{D}_{6}\right) \delta: 5.91\left(\mathrm{~m},{ }^{1} J_{\mathrm{HSi}}=\right.$ $222.8 \mathrm{~Hz}, 1 \mathrm{H} \mathrm{SiH}), 4.80-3.94$ (m, 8H Cp), 1.33-1.22 (m, $18 \mathrm{H}$ ${ }^{t} \mathrm{Bu} \mathrm{CH}_{3}$ ) ppm; ${ }^{13} \mathrm{C} \mathrm{NMR}\left(126 \mathrm{MHz}, \mathrm{C}_{6} \mathrm{D}_{6}\right.$ ) $\delta: 79.0$ (pseudo t, $J_{\mathrm{PC}}$ $=21.5 \mathrm{~Hz}, \mathrm{Cp}$ ), 74.9 (pseudo t, $\left.J_{\mathrm{PC}}=4.1 \mathrm{~Hz}, \mathrm{Cp}\right), 72.4(\mathrm{~m}, \mathrm{Cp}$ ), 72.1 (pseudo t, $J_{\mathrm{PC}}=5.0 \mathrm{~Hz}, \mathrm{Cp}$ ), 66.3 (pseudo t, $J_{\mathrm{PC}}=12.1 \mathrm{~Hz}$, Cp ipso C), 30.9 (pseudo $\mathrm{t}, J_{\mathrm{PC}}=6.9 \mathrm{~Hz},{ }^{t} \mathrm{Bu} \mathrm{CH}_{3}$ ), 30.9-30.8 (m, $t \mathrm{Bu} \quad \mathrm{C}$ q) ppm. Elemental analysis (\%) $\mathrm{C}_{18} \mathrm{H}_{27} \mathrm{ClFeP}_{2} \mathrm{Si} \cdot 0.15 \mathrm{C}_{18} \mathrm{H}_{28} \mathrm{FeP}_{2}$ calculated: C: 52.051, H: 6.588, found: $\mathrm{C}$ : 52.151, $\mathrm{H}:$ 6.536. MS (LIFDI-HR): $\mathrm{m} / \mathrm{z} 362.10107$ $\left([\mathrm{M}-\mathrm{SiCl}+\mathrm{H}]^{+}\right.$100\%), $396.06247\left([\mathrm{M}-\mathrm{Si}+\mathrm{H}]^{+} 20 \%\right)$ calculated: 396.06259 .

\section{Acknowledgements}

The authors thank Prof. Gudat for helpful discussions and the Deutsche Forschungsgemeinschaft (PI 353/8-1 and PI 353/9-1) and OTKA NN 113772 within the framework of the ERA-Chemistry program for financial support. We also thank the EU-COST network CM1302 "Smart Inorganic Polymers" (SIPs) for funding an STSM. Moreover, we are grateful to Dr Linne and his mass spectrometry team at the University of Marburg.

\section{Notes and references}

1 D. E. Herbert, U. F. J. Mayer and I. Manners, Angew. Chem., Int. Ed., 2007, 46, 5060-5081.

2 I. Manners and U. Vogel, in Modern Cyclophane Chemistry, ed. R. H. Gleiter, Henning, Wiley-VCH Verlag GmbH \& Co. KGaA, Weinheim, Germany, 2004, pp. 415-433.

3 I. Manners, Science, 2001, 294, 1664-1666.

4 P. Nguyen, P. Gomez-Elipe and I. Manners, Chem. Rev., 1999, 99, 1515-1548.

5 M. Herberhold, Angew. Chem., Int. Ed. Engl., 1995, 34, 1837.

6 R. Broussier, A. Da Rold, B. Gautheron, Y. Dromzee and Y. Jeannin, Inorg. Chem., 1990, 29, 1817-1822.

7 C. Moser, F. Belaj and R. Pietschnig, Chem. - Eur. J., 2009, 15, 12589-12591.

8 Y. Tanimoto, Y. Ishizu, K. Kubo, K. Miyoshi and T. Mizuta, J. Organomet. Chem., 2012, 713, 80-88.

9 C. Moser, F. Belaj and R. Pietschnig, Phosphorus Sulfur Relat. Elem., 2015, 190, 837-844.

10 D. M. Khramov, E. L. Rosen, V. M. Lynch and C. W. Bielawski, Angew. Chem., Int. Ed., 2008, 47, 22672270 .

11 U. Siemeling, C. Färber, M. Leibold, C. Bruhn, P. Mücke, R. F. Winter, B. Sarkar, M. von Hopffgarten and G. Frenking, Eur. J. Inorg. Chem., 2009, 2009, 4607-4612.

12 S. Spirk, F. Belaj, J. H. Albering and R. Pietschnig, Organometallics, 2010, 29, 2981-2986.
13 R. Pietschnig and A. Orthaber, Eur. J. Inorg. Chem., 2006, 22, 4570-4576.

14 C. Moser, A. Orthaber, M. Nieger, F. Belaj and R. Pietschnig, Dalton Trans., 2006, 3879-3885.

15 M. Bender, E. Niecke, M. Nieger and R. Pietschnig, Eur. J. Inorg. Chem., 2006, 380-384.

16 R. Pietschnig, J. Chem. Soc., Chem. Commun., 2004, 5, 546547.

17 D. Lange, E. Klein, H. Bender, E. Niecke, M. Nieger, R. Pietschnig, W. W. Schoeller and H. Ranaivonjatovo, Organometallics, 1998, 17, 2425-2432.

18 B. D. Rekken, T. M. Brown, J. C. Fettinger, H. M. Tuononen and P. P. Power, J. Am. Chem. Soc., 2012, 134, 6504-6507.

19 D. Kargin, Diploma Thesis, University of Kassel, 2013.

20 H. J. Reich and R. R. Dykstra, Organometallics, 1994, 13, 4578-4585.

21 R. Wolf, A. Schisler, P. Lönnecke, C. Jones and E. HeyHawkins, Eur. J. Inorg. Chem., 2004, 16, 3277-3286.

22 B. Riegel, A. Pfitzner, G. Heckmann and H. Binder, Z. Anorg. Allg. Chem., 1995, 621, 1989-1994.

23 R. T. Boere and Y. Zhang, J. Organomet. Chem., 2005, 690, 2651-2657.

24 R. E. Weston, J. Am. Chem. Soc., 1954, 76, 2645.

25 P. Schwerdtfeger, L. Laakkonen and P. Pyykkö, J. Chem. Phys., 1992, 96, 6807.

26 L. Nyulaszi, Tetrahedron, 2000, 56, 79-84.

27 L. Nyulaszi, J. Phys. Chem., 1995, 99, 586-591.

28 M. Ma, A. Stasch and C. Jones, Chem. - Eur. J., 2012, 18, 10669-10676.

29 R. J. Gillespie and I. Hargittai, The VSEPR Model of Molecular Geometry, Allyn and Bacon, Boston, 1991.

30 R. A. Musgrave, A. D. Russell, G. R. Whittell, M. F. Haddow and I. Manners, Organometallics, 2015, 34, 897-907.

31 R. S. Ghadwal, H. W. Roesky, S. Merkel, J. Henn and D. Stalke, Angew. Chem., Int. Ed., 2009, 121, 57935796.

32 W.-W. du Mont and M. Grenz, Chem. Ber., 1985, 118, 10451049.

33 M. Takahashi, S. Tsutsui, K. Sakamoto, M. Kira, T. Müller and Y. Apeloig, J. Am. Chem. Soc., 2001, 123, 347-348.

34 L. Jafarpour, E. D. Stevens and S. P. Nolan, J. Organomet. Chem., 2000, 606, 49-54.

35 G. Becker, M. Gekeler, H.-M. Hartmann and O. Mundt, in Synthetic Methods of Organometallic and Inorganic Chemistry: Groups 1, 2,13, and 14, ed. N. Auner and U. Klingebiel, Thieme, Stuttgart, 1996, vol. 2, p. 156.

36 G. M. Sheldrick, Acta Crystallogr., Sect. A: Fundam. Crystallogr., 2008, 64, 112-122.

37 L. J. Farrugia, J. Appl. Crystallogr., 1999, 32, 837-838.

38 M. Nardelli, J. Appl. Crystallogr., 1995, 28, 659.

39 C. F. Macrae, P. R. Edgington, P. McCabe, E. Pidkock, G. P. Shields, R. Taylor, M. Towler and J. van der Streek, J. Appl. Crystallogr., 2006, 39, 453-457.

40 M. J. Frisch, G. W. Trucks, H. B. Schlegel, G. E. Scuseria, M. A. Robb, J. R. Cheeseman, G. Scalmani, V. Barone, B. Mennucci, G. A. Petersson, H. Nakatsuji, M. Caricato, 
X. Li, H. P. Hratchian, A. F. Izmaylov, J. Bloino, G. Zheng, J. L. Sonnenberg, M. Hada, M. Ehara, K. Toyota, R. Fukuda, J. Hasegawa, M. Ishida, T. Nakajima, Y. Honda, O. Kitao, H. Nakai, T. Vreven, J. A. Montgomery Jr., J. E. Peralta, F. Ogliaro, M. Bearpark, J. J. Heyd, E. Brothers, K. N. Kudin, V. N. Staroverov, T. Keith, R. Kobayashi, J. Normand, K. Raghavachari, A. Rendell, J. C. Burant, S. S. Iyengar, J. Tomasi, M. Cossi, N. Rega, J. M. Millam, M. Klene, J. E. Knox, J. B. Cross, V. Bakken, C. Adamo, J. Jaramillo, R. Gomperts, R. E. Stratmann, O. Yazyev,
A. J. Austin, R. Cammi, C. Pomelli, J. W. Ochterski, R. L. Martin, K. Morokuma, V. G. Zakrzewski, G. A. Voth, P. Salvador, J. J. Dannenberg, S. Dapprich, A. D. Daniels, O. Farkas, J. B. Foresman, J. V. Ortiz, J. Cioslowski and D. J. Fox, Gaussian 09, Revision B.01, Gaussian Inc., Wallingford, CT, 2010.

41 G. Schaftenaar and J. H. Noordik, J. Comput.-Aided Mol. Des., 2000, 14, 123-134.

42 A. Todd and T. K. Keith, AIMAll 11.10.16, Gristmill Software, Overland Park, 2011, http://aim.tkgristmill.com. 